Vol. 44, N. 2 : pp. 191 - 196, June, 2001

ISSN 1516-8913 Printed in Brazil

\title{
An Improved Method for Transformation of Lettuce by Agrobacterium tumefaciens with a Gene that Confers Freezing Resistance
}

\author{
Marcos Pileggi ${ }^{*}$, Albanin Aparecida Mielniczki Pereira ${ }^{1}$, Joandrei dos Santos Silva ${ }^{1}$, Sônia \\ Alvim Veiga Pileggi ${ }^{1}$ and Desh Pal S. Verma ${ }^{2}$ \\ ${ }^{I}$ Departamento de Biologia Geral, Setor de Ciências Biológicas e da Saúde, Universidade Estadual de Ponta \\ Grossa, Campus Uvaranas, Av. Carlos Cavalcanti, 4748, 84030-000, Ponta Grossa, PR, Brazil; ${ }^{2}$ Plant \\ Biotechnology Center, Ohio State University, 1060 Carmack Road, Columbus, OH 43210, USA
}

\begin{abstract}
An efficient method for constructing transgenic lettuce cultivars by Agrobacterium tumefaciens was described by Torres et al., 1993. In the present work, an improvement of the above procedure is described and applied to transform the cultivar Grand Rapids with a mutated P5CS gene. The major modifications were concerned with turning more practical the transformation and regeneration protocols. Also we tried to improve transformation steps by increasing injured area in explants and prolonging co-cultivation with Agrobacteria (in larger concentration). A more significant selective pressure was used against non-transformed plants and bacteria. In these work we were concerned to obtain $T_{1}$ and $T_{2}$ seeds. The P5CS gene codes for a $\Delta^{1}$-pyrroline-5-carboxylate synthetase, a bifunctional enzyme that catalyzes two steps of proline biosynthesis in plants (Zhang et al., 1995; Peng et al., 1996), while the mutated gene is insensitive to feedback inhibition by proline. The potential benefit of this gene is to confer water stress resistance (drought, salt, cold) due to increased intracellular levels of proline that works like an osmoprotectant. In this work could obtain and characterize transgenic lettuce lineages which are resistant to freezing temperature.
\end{abstract}

Key words: Stress resistance; cold resistance; transgenic; lettuce; proline

\section{INTRODUCTION}

The development of new crops capable of high yields under drought, salinity and cold environments has been difficult due to the polygenic nature of these traits. Plants have evolved different mechanisms to overcome water deficit (McCue \& Hanson, 1990). Proline acts as an osmolyte and it is accumulated in many bacteria and plants under osmotic stress (Delauney \& Verma, 1993). The major idea to be tested is that increased synthesis of a specific osmolyte can help to develop stress tolerance with an eventual improvement in crop yield.

Overexpression of the $\Delta^{1}$-pyrroline-5-carboxylate synthetase (P5CS) gene, the first enzyme of the proline biosynthesis pathway enhances proline production in transgenic plants (Kishor et al., 1995). The level of proline can be increased 2 to 3 times (Hong, 1997) if the feedback inhibition by proline is removed by site directed mutagenesis of

\footnotetext{
* Author for correspondence
} 
this gene (Zhang et al., 1995). Lettuce (Lactuca sativa L. c.v. Grand Rapids) was chosen as a model plant due to its fast growth and agronomic value. The protocol described by Torres et al. 1993 to construct transgenic lettuce lineages by Agrobacterium tumefaciens was not adequate to obtain transgenic lettuce plants, probably due to incompatibility with the cultivar involved. This paper describes adaptations and modifications to improve transformation and regeneration efficiency of Grand Rapids lettuce cultivar, as a model to test the resistance to freezing temperature.

\section{MATERIAL AND METHODS}

The lettuce (Lactuca sativa L.) cultivar Grand Rapids was used in this work. The techniques for co-cultivation with Agrobacterium tumefaciens, selection of kanamicin resistant explants, as well as for regeneration of shoots and roots, are described in this section.

Source of explants: Seeds of Lactuca sativa L. c.v. Grand Rapids were disinfected by soaking in a $10 \%$ solution of household bleach containing $0.1 \%$ Tween 20 for 25 minutes, followed by three rinses with sterile distilled water. The seeds were then germinated on MSO (4.3 g/L MS salts [Gibco]; 1 $\mathrm{ml} / \mathrm{L}$ B5 vitamins [B5 vitamin stock contains 100 $\mathrm{mg} / \mathrm{mL}$ myo-inositol; $10 \mathrm{mg} / \mathrm{mL}$ thiamine- $\mathrm{HCl} ; 1$ $\mathrm{mg} / \mathrm{mL}$ nicotinic acid; $1 \mathrm{mg} / \mathrm{mL}$ pyridoxine- $\mathrm{HCl}$; $30 \mathrm{~g} / \mathrm{L}$ sucrose and $0.7 \%$ agar [Bacto-Difco]; $\mathrm{pH}$ 5.7) plates (30 to 50 seeds per dish). The cultures were continuously illuminated with cool white fluorescent light at a constant temperature of 25 ${ }^{\circ} \mathrm{C}$, for a minimum of 16 hours. When aseptically germinated seedlings were 24 to 48 hours old, cotyledons were excised near the cotiledonary node, and cut in 6 or 8 pieces to increase the wound, originating the explants for Agrobacterium infection.

Transformation: Explants were pre-cultured upside down for 2 days on MS104 (MSO; 0.05 $\mathrm{mg} / \mathrm{L}$ naphthaleneacetic acid [NAA]; $0.2 \mathrm{mg} / \mathrm{L}$ benzyladenine $[\mathrm{BA}])$ to allow initial growth.

A. tumefaciens LBA4404 carrying plasmid pBIF414, which contains NPTII, (the kanamicin resistance gene), the $\beta$-glucuronidase gene (GUS activity) and a mutated P5CS ( $\Delta^{1}$-pyrroline-5carboxylate synthetase gene), located between TDNA borders, was inoculated in $10 \mathrm{~mL}$ of YEP medium (peptone $10 \mathrm{~g} / \mathrm{L}$; yeast extract $10 \mathrm{~g} / \mathrm{L}$; $\mathrm{NaCl} 5 \mathrm{~g} / \mathrm{L}$ ) with $50 \mathrm{mg} / \mathrm{L}$ of kanamicin in $125 \mathrm{~mL}$ Erlenmeyer flasks. The cultures were incubated at $28^{\circ} \mathrm{C}$ overnight in an orbital shaker at $300 \mathrm{rpm}$.

Inoculation of cotyledons: Cotyledons were dipped into A. tumefaciens grown overnight cultures (diluted 1 to 10 with MSO to $10^{9}$ cells $/ \mathrm{mL}$ ), and gently blotted dry as soon as all wounded edges had contacted the inoculum, by a fast dive of the explant, without over-soaking the tissue. The explants were placed upside down on MS104 plates, and incubated at $25{ }^{\circ} \mathrm{C}$ for three days. The explants were then transferred to a selective medium (MS104; containing $500 \mathrm{mg} / \mathrm{L}$ carbenicilin and $300 \mathrm{mg} / \mathrm{L}$ kanamicin), and incubated at $25{ }^{\circ} \mathrm{C}$ for 14 days in parafilm sealed Petri dishes or magenta boxes to conserve humidity (From this moment on, all the Petri plates and magenta boxes were sealed with parafilm to retain humidity). Explants were cut, when possible, to obtain isolated shoots (Figure 1), and transferred to fresh selection medium. Following shoot initiation, explants were transferred each 14 days to selection medium, until strong shoots could be transferred to rooting medium (MSO with $0,6 \%$ agar, $500 \mathrm{mg} / \mathrm{L}$ carbenicilin; $100 \mathrm{mg} / \mathrm{mL}$ kanamicin, $0.5 \mathrm{mg} / \mathrm{L}$ NAA) in magenta boxes (Figure 2).

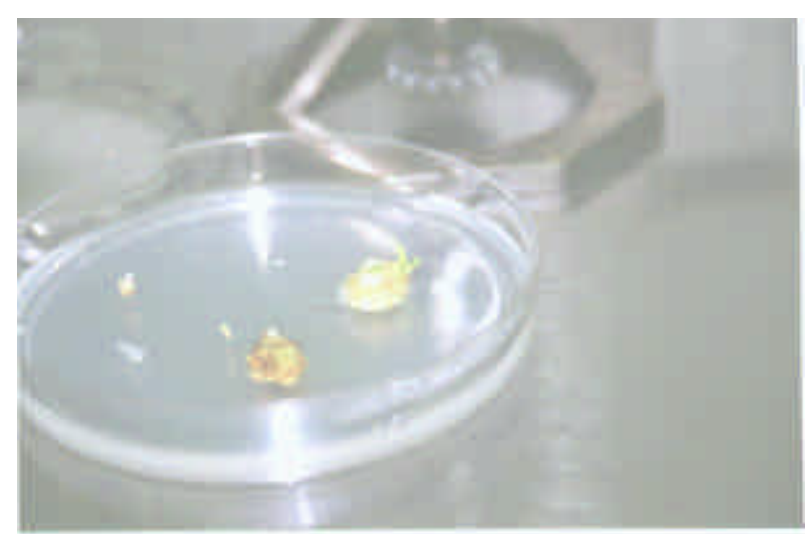

Figure 1 - Explants in Selection Medium with isolated sites of transformation 


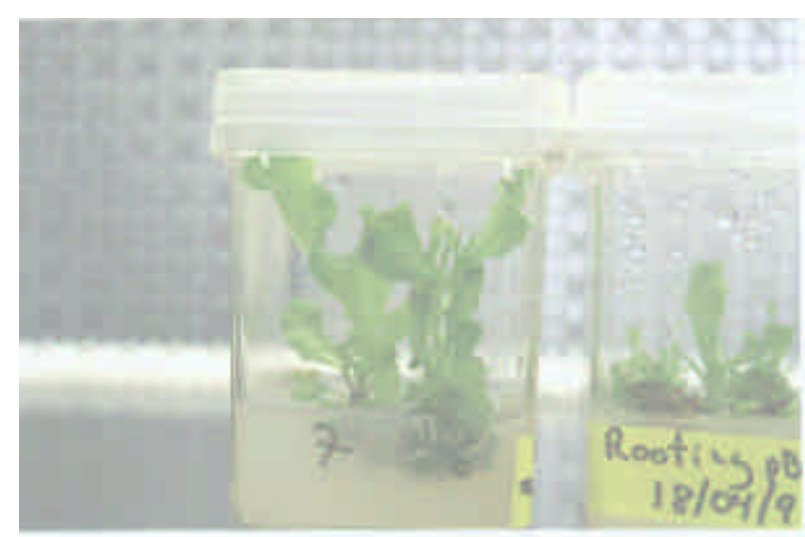

Figure 2 - Explants with strong shoots in rooting medium

Seed harvest: Plantlets with strong roots were planted in sterile soil in small pots. The pots were placed in a large tray containing a $2 \mathrm{~cm}$ layer of water (Figure 3). The tray was sealed with Saran paper to keep a high moisture environment, and maintained at room temperature $\left(22^{\circ} \mathrm{C}\right)$ until the plants started to grow (4 to 5 days). During this period, the Saran wrap was opened gradually until it was completely removed. The growing plants were then transferred to a greenhouse and kept there more 2-3 days to adapt to relative low humidity from in vitro culture to greenhouse environment. The plants were removed from the pots with all adhered soil, and transferred into bigger pots containing different soil types. In the greenhouse, the lettuce plants grew very fast, and could reach about one meter height. To avoid infestation by insects and diseases, a solution based on cured tobacco leaves extract was used, as well as manual catching of insects. Nitrogen feeding was decreased gradually to induce blooming (Figure 4). Blooming took two months, and the plants were self-pollinated. At this point, nitrogen and boron feeding were restarted to guarantee seed filling and maturation. The seeds were mature 12 days after the start of blooming. To prevent seed loss, the flowers were removed one by one. High humidity was avoided by placing the pots in drier areas of the greenhouse. Each flower produced 10 to 25 seeds. (Figure 5). The seeds were collected when dry. To break dormancy the seeds were exposed to cold temperature $\left(4{ }^{\circ} \mathrm{C}\right)$ for two days or germinated under red light. The temperature was maintained at about $26{ }^{\circ} \mathrm{C}$ by day and $21{ }^{\circ} \mathrm{C}$ by night, to improve the seed formation.

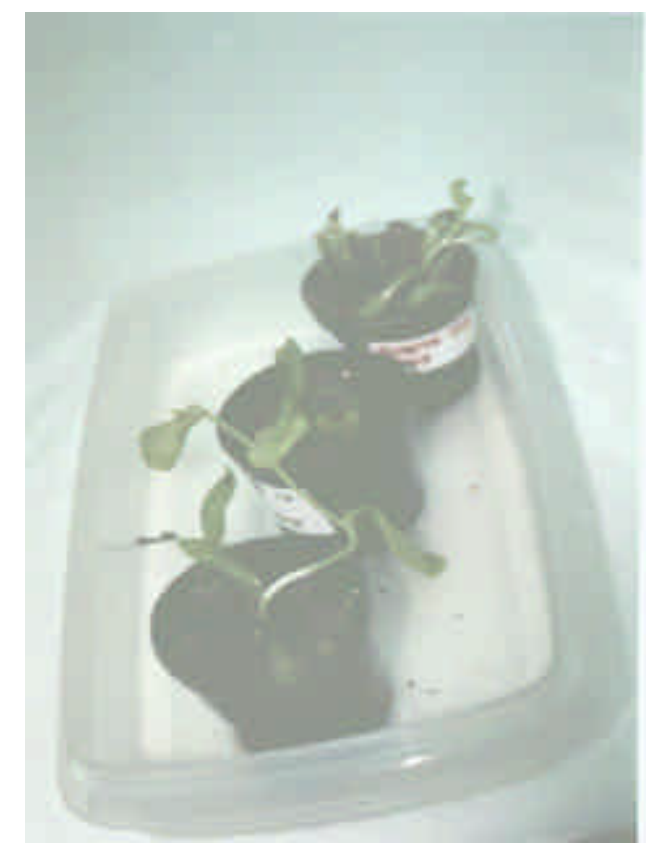

Figure 3 - Plants with strong roots in small pots with sterile soil

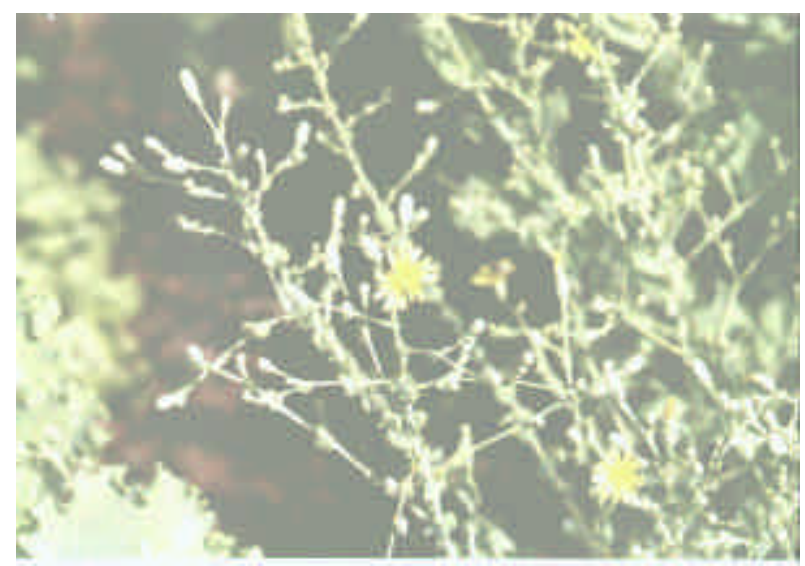

Figure 4 - Flowers rising in terminal position

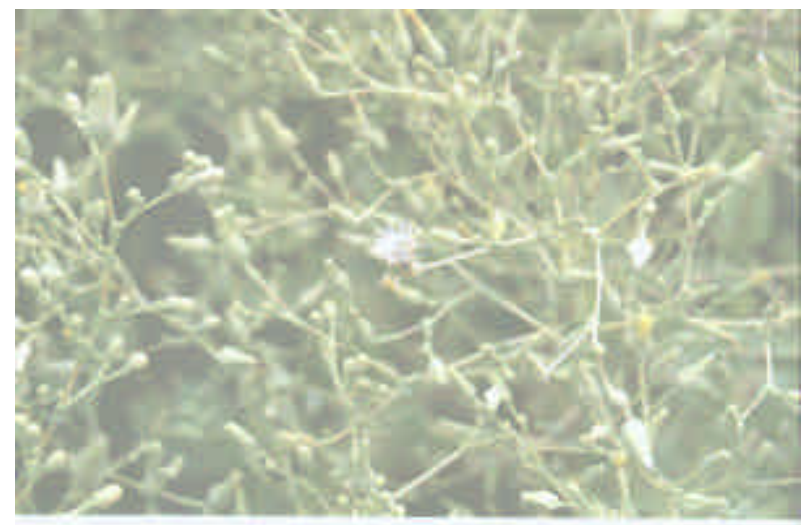

Figure 5 - Flowers with structures that promote wind dissemination of the seeds 
Histochemical staining for GUS activity: The GUS staining procedure was modified from Jefferson et al. (1987). The substrate was 5bromo-4-chloro-3-indolyl-glucoronidase (X-Glu. Gibco-BRL). The tissue fragments were added to $100 \mu \mathrm{L}$ of staining solution in microcentrifuge tubes, and incubated at $37{ }^{\circ} \mathrm{C}$ for 2 to $4 \mathrm{hs}$ (Figure 6).

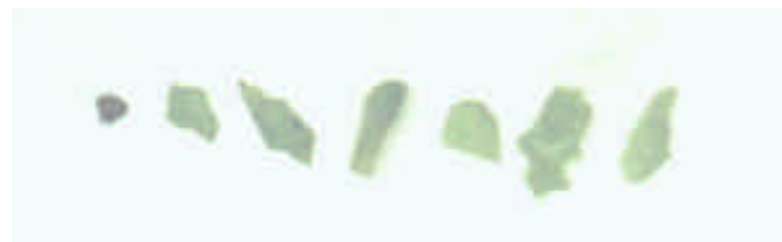

Figure 6 - GUS analysis for fragments of transgenic plants. Only blue spot means GUS positive result (fragments 1, whole fragment, and 3, with spots)

Temperature resistance in rich proline lettuce: From each independent transgenic lineage, 15 seeds were grown in MSO plates. Only the germinated seeds were counted in "Total" (labeled in Table 1). Three temperatures were chosen: $0{ }^{\circ} \mathrm{C}$, $4{ }^{\circ} \mathrm{C}$ and $37{ }^{\circ} \mathrm{C}$. The time at which the plants were submitted to sets of temperatures was 10 hours. After that, the material was recovered by constant illumination and temperature of $25{ }^{\circ} \mathrm{C}$. Control was the wild type c.v. (Grand Rapids) with no transformation.

\section{RESULTS AND DISCUSSION}

When we used the first protocol, (Torres et al., 1993), we got no transformed explant, probably because another cultivar was used (South Bay). We accomplished some adaptations based on protocols of Torres et al. (1993), and Horsch et al. (1988). The major modifications related to the first one are listed here. No cheesecloth squares were used to keep the seeds together. This procedure brought some difficulty in catching the seeds into the cheesecloth tissue. As seeds were immersed in bleach solution, they could be easily decanted and washed in sterilized water. After that, they were picked with a wide spatula. No vacuum was used, because desinfestation was still very efficient. No filter paper platform over liquid media was used to germinate the seeds, because of difficulty to manipulate inborn plantlets. We increased the number of cut pieces from cotyledons, from 2 to 6 or 8 , to improve the chance of infection by Agrobacterium and transformation efficiency.

The time for pre-culture of explants was increased from 30 minutes to 2 days, with the purpose to improve the contact between plant and bacteria, and therefore transformation efficiency.

Agrobacterium was inoculated in YEP medium as this was more appropriate to grow this bacteria than LB. The cultures were incubated in an orbital shaker at $300 \mathrm{rpm}$ rather than $150 \mathrm{rpm}$, with the purpose to get more bacteria to inoculation. Cotyledons were dipped into A. tumefaciens overnight cultures (diluted 1 to 10 with MSO to $10^{9}$ cells $/ \mathrm{mL}$ ), and gently blotted dry, as soon as all wounded edges had contacted the inoculum, rather than over-soaking the tissue for 10 minutes as over-soaking could damage the plant cells. Overnight cultures of A. tumefaciens were diluted 1 to 10 with MSO media with no centrifugation and suspension in MSO media. Kanamycin was also diluted and its residue could be helpful on initial transformed explants selection, with little damage in sensitive lettuce tissue. No acetosyringone or syringaldehyde was used to stimulate bacterial transformation, considering that no increase on transformation's rates was observed in lettuce (Torres, personal communication). To improve selection of transformed explants, carbenicilin (to kill Agrobacterium) level was raised from $100 \mathrm{mg} / \mathrm{mL}$ to $500 \mathrm{mg} / \mathrm{mL}$; and kanamicin (to select resistant explants) concentration was raised from $50 \mathrm{mg} / \mathrm{mL}$ to 300 $\mathrm{mg} / \mathrm{mL}$. We observed that just NAA was enough to induce rooting, so the hormones benzyladenine, isopentenyladenine and zeatin were not used in this medium.

About 84 to $88 \%$ of tissue culture platelets could be recovered in the greenhouse like fully mature plants. About 12 to $16 \%$ plants (3-4 plants out of 25) showed abnormal phenotypes as revealed by smaller leaves that faded soon. These phenotypes are probably due to somatic variation caused by hormones during callus growth and plant regeneration.

We were able to obtain 18 independent transformed lineages; 15 of them produced enough seeds to be tested in temperature resistance assays. Protocols from Torres et al. (1988) and Horsch et al. (1993) did not describe how to obtain seeds 
from transgenic plants. We got seeds from $T_{1}$ and $\mathrm{T}_{2}$ generations. $\mathrm{T}_{1}$ generation was obtained from in vitro plant culture, and $\mathrm{T}_{2}$ from ex vitro culture.

To select transformed plants, was used constant selective pressure, kanamicyn. We also used a GUS staining over leaves fragments, choosing only the positive ones. As a matter of fact, $G U S$ and NPTII genes are close to P5CS gene, so selection for both genes could be indirectly selective to P5CS too.
The protocol for transformation and regeneration of lettuce with A. tumefaciens was adapted from Torres et al.. (1993), and Horsch et al. (1988). Unfortunately, both original protocols failed to promote transformation of cultivar Grand Rapids. Transformation and regeneration of this cultivar was successful using the methodology described in this paper. Also we got the acclimatization of ex vitro plants and transgenic seed production. The previous papers did not repeat these achievements.

Table 1 - Resistance results to stress temperatures in 15 independent transgenic strains of lettuce c.v. Grand Rapids

\begin{tabular}{|c|c|c|c|c|c|c|}
\hline \multirow{3}{*}{ Lineage } & \multicolumn{6}{|c|}{ Temperatures } \\
\hline & \multicolumn{2}{|c|}{$0{ }^{\circ} \mathrm{C}$} & \multicolumn{2}{|c|}{$4{ }^{\circ} \mathrm{C}$} & \multicolumn{2}{|c|}{$37^{\circ} \mathrm{C}$} \\
\hline & Total & Survived & Total & Survived & Total & Survived \\
\hline Control & 15 & 0 & 15 & 15 & 15 & 0 \\
\hline Lineage 1 & 15 & 15 & 15 & 15 & 5 & 0 \\
\hline Lineage 2 & 15 & 15 & 15 & 15 & 10 & 0 \\
\hline Lineage 3 & 15 & 0 & 15 & 15 & 14 & 0 \\
\hline Lineage 4 & 15 & 15 & 15 & 15 & 10 & 0 \\
\hline Lineage 5 & 15 & 15 & 15 & 15 & 13 & 0 \\
\hline Lineage 6 & 12 & 12 & 15 & 15 & 13 & 0 \\
\hline Lineage 7 & 15 & 15 & 15 & 15 & 12 & 0 \\
\hline Lineage 8 & 5 & 0 & 10 & 10 & 15 & 10 \\
\hline Lineage 9 & 15 & 15 & 15 & 15 & 15 & 10 \\
\hline Lineage 10 & 15 & 0 & 15 & 15 & 8 & 5 \\
\hline Lineage 11 & 15 & 15 & 15 & 15 & 15 & 11 \\
\hline Lineage 12 & 8 & 0 & 15 & 15 & 15 & 15 \\
\hline Lineage 13 & 15 & 15 & 15 & 15 & 15 & 15 \\
\hline Lineage 14 & 15 & 15 & 15 & 15 & 15 & 15 \\
\hline Lineage 15 & 15 & 15 & 15 & 15 & 15 & 15 \\
\hline Lineage $\Sigma$ & 205 & 162 & 220 & 220 & 190 & 96 \\
\hline
\end{tabular}

Lineages 16, 17 and 18 did not germinated.

For plants, the major problem of freezing temperature is the ice crystals. When intracellular water freezes, there is an expansion in volume of ice crystals that can injure cell membranes. When the plant is put to recover, all the intracellular content is lost and the plant dies. As shown in Table 1 , considering $0{ }^{\circ} \mathrm{C}$ evaluation, the results suggested that the P5CS mutated gene confers a high proline concentration as well as a high osmotic potential and a need to keep water without freezing, compared with control lineage. This excess of proline could help the plant in recovering phase, putting up more nitrogen and carbon supplies. However, some lineages showed no resistance to this temperature $(3,8,10$ and 12). This could mean that some lineages had their transgenes in tandem inserts inactive by heterocramatization. Future experiments using
Southern Blot could be fitted to check this explanation.

The temperature of $4{ }^{\circ} \mathrm{C}$ was chosen at first, because a low temperature could lead to water stress. As we can see, no differences among the control and transgenic lines were observed at $4{ }^{\circ} \mathrm{C}$. This could be explained by the fact that the Grand Rapids are a winter cultivar, with a natural resistance to cold temperatures (but not freezing).

At $37{ }^{\circ} \mathrm{C}$, the results showed that proline had a relevant role of resistance in transgenic strains. The same hypothesis for protection in leaves and in the recovering phase described for $0{ }^{\circ} \mathrm{C}$ could be considered here. But now an additional hypothesis concerned with osmotic root potential could be accounted. At high temperatures, water evaporates very quickly, increasing salt concentration, and, therefore increasing osmotic potential of soil, which results in low water absorption by plant's 
roots. Proline could increase osmotic potential of the roots, which could easily absorve water.

In all temperature treatments, we postulated that the position of inserts must cause important effects, under different physiological conditions. Besides, transgenes could be inactivated in a multi copy way due to expression pattern presented by plants. So, independent transformed lineages could show distinct behaviors over different temperature treatments, as we can see in Table 1.

This approach turns very reasonable the achievement of new assays about stress environment, using, for instance, lineages of crops.

\section{ACKNOWLEDGMENTS}

Thanks are due to CNPq for a fellowship given to M.P.; to Dr. Marguerite Quoirin for her assistance in determining rooting medium conditions and to Dr. Zonglie Hong and Dr. Zhongming Zang for their assistance in all steps of this work.

\section{RESUMO}

Um método eficiente de obtenção de cultivares de alface por meio de transformação com Agrobacterium tumefaciens foi descrito por Torres et al., 1993. Neste trabalho foi desenvolvido um procedimento melhorado a partir do trabalho descrito acima foi aplicado para transformação da cultivar de alface Grand Rapids com o gene mutado P5CS. As principais modificações nos protocolos de transformação e regeneração, com o objetivo de torná-los mais práticos. Também foi procurado o melhoramento das etapas de transformação no sentido de se aumentar a infecção, além do aumento no tempo de co-cultivo com Agrobacterium (em uma alta concentração celular). Maior pressão seletiva foi utilizada contra plantas não transformadas e bactérias. Neste trabalho também se trabalhou na produção de sementes das gerações $T_{1}$ e $T_{2}$, para que se pudesse fazer os ensaios fisiológicos e . Este gene codifica para $\Delta^{1}$-pirrolina-5carboxilato sintetase, uma enzima bifuncional que catalisa dois passos na biossíntese de prolina em plantas (Zhang et al., 1995; Peng et al., 1996), só que neste caso se tornou insensível para inibição por retroalimentação por prolina. O potencial deste gene é conferir resistência ao estresse hídrico (seca, alta concentração salina, frio) devido ao aumento na concentração de prolina intracelular, que funciona como um osmoprotetor. Neste trabalho foram obtidas e analisadas linhagens de alface transgênicas resistentes ao congelamento.

\section{REFERENCES}

Delauney, A. J. and Verma D. P. S. (1993), Proline biosynthesis and osmoregulation in plants. Plant J., 4, 215-223

Hong, Z. (1997), Removal of feedback inhibition of $\Delta^{1}$ pyrroline-5-carboxylate synthetase results in proline overproduction, oxidative stress relief and salt tolerance in transgenic plants. Master in Sciences Thesis, Ohio State University, Ohio, USA

Horsch, R. B.; Fry, J.; Hoffmann, N.; Neidermeyer, J.; Rogers, S.G. and Fraley, R.T. (1988), Leaf disc transformation. In-Plant Molecular Biology Manual, eds. Gelvin, S.B.; Schilperoort, R.A. and Verma, D.P.S. Kluwer Academic Publishers, Dordrecht., A5, $1-9$

Kishor, P. B. K.; Hong, Z.; Miao, G.-H; Hu, C.A. and Verma, D.P.S. (1995), overexpression of $\Delta^{1}$ pyrroline-5-carboxylate synthetase increase proline production and help maintain osmotic potential in transgenic plants during stress. Plant Physiol., 108, 1387-1394

McCue, K. F. and Hanson, A. D. (1990), Drought and salt tolerance: towards understanding and application. TIBTECH, 8, 358-362

Peng, Z.; Lu, Q. and Verma, D. P. S. (1996), Reciprocal regulation of $\Delta^{1}$-pyrroline-5-carboxylate synthetase and proline dehydrogenase genes controls proline levels during and after osmotic stress in plants. Mol. Gen. Genet., 253, 334-341

Torres, A. C.; Cantliffe, D. J.; Laughner, B.; Bieniek, M.; Nagata, R.; Ashraf, M. and Ferl, R. J. (1993), Stable transformation of lettuce cultivar South Bay from cotyledon explants. Plant Cell, Tissue and Organ Culture, 34, 279-285

Zhang, C.-S.; Lu, Q. and Verma, D. P. S. (1995), Removal of feedback inhibition of $\Delta^{1}$-pyrroline-5carboxylate synthetase, a binfunctional enzyme catalyzing the first two steps of proline biosynthesis in plants. The Journal of Biological Chemistry, 270, 20491-20496

Received: December 23, 1999; Revised: July 31, 2000; Accepted: August 17, 2000. 